May 2012

\title{
Spinal muscular atrophy:clinical spectrum and genetic mutations in Pakistani children
}

\author{
S. H. Ibrahim \\ Aga Khan University, shahnaz.ibrahim@aku.edu \\ Tariq Moatter \\ Aga Khan University, tariq.moatter@aku.edu \\ Ali Faisal Saleem \\ Aga Khan University,, ali.saleem@aku.edu
}

Follow this and additional works at: https://ecommons.aku.edu/

pakistan_fhs_mc_women_childhealth_paediatr

Part of the Pediatrics Commons

\section{Recommended Citation}

Ibrahim, S., Moatter, T., Saleem, A. F. (2012). Spinal muscular atrophy:clinical spectrum and genetic mutations in Pakistani children. Neurology India, 60(3), 294-298.

Available at: https://ecommons.aku.edu/pakistan_fhs_mc_women_childhealth_paediatr/163 


\section{Spinal muscular atrophy: Clinical spectrum and genetic mutations in Pakistani children}

Article in Neurology India · May 2012

DOI: $10.4103 / 0028-3886.98514 \cdot$ Source: PubMed

CITATIONS

5

3 authors, including:

\section{Tariq Moatter}

Aga Khan University, Pakistan

92 PUBLICATIONS 872 CITATIONS

SEE PROFILE
READS

160

Some of the authors of this publication are also working on these related projects:

Project Genotyping and Phylogenetic Analysis of Hepatitis B Virus and Identification of its Binding Protein in Serum View project

Project

Polio vaccine innovation View project
Ali Faisal Saleem

Aga Khan University, Pakistan

47 PUBLICATIONS 258 CITATIONS

SEE PROFILE 
ISSN 0028-3886

May-June 2012 / Vol 60 / Issue 3

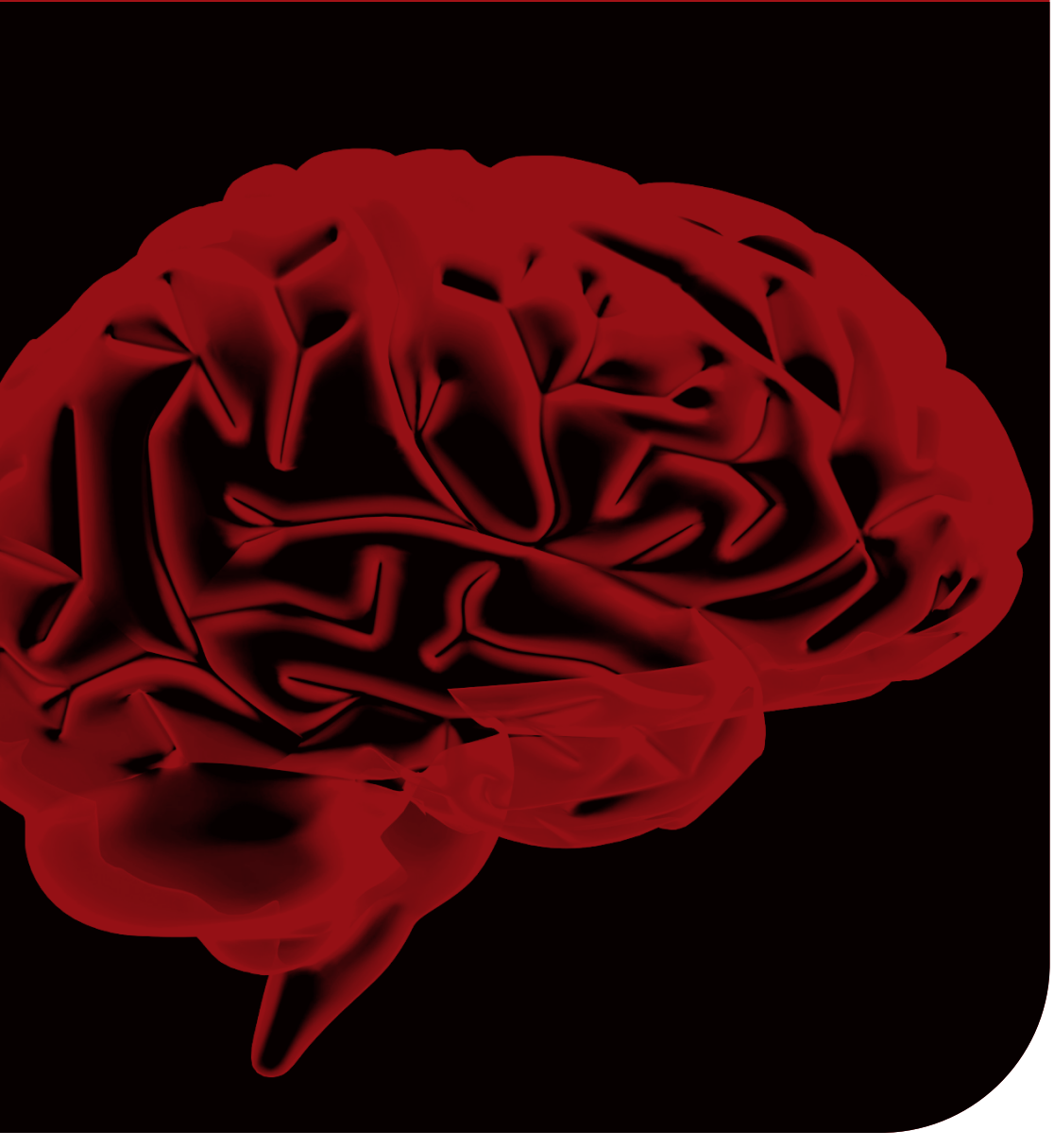

www.neurologyindia.com

Neurology India

Official Publication of the Neurological Society of India 


\title{
Spinal muscular atrophy: Clinical spectrum and genetic mutations in Pakistani children
}

\author{
Shahnaz Ibrahim, Tariq Moatter ${ }^{1}$, Ali Faisal Saleem \\ Departments of Pediatrics and Child Health, ${ }^{1}$ Pathology and Microbiology, Aga Khan University, Karachi, Pakistan
}

Address for correspondence:

Associate Prof. Shahnaz Hamid

Ibrahim,

Aga Khan University Hospital,

Karachi 74800, Pakistan.

E-mail: shahnaz.ibrahim@aku.edu

Received : 03-04-2012

Review completed : 17-05-2012

Accepted : 10-06-2012

\begin{abstract}
Background: In Pakistan the rate of consanguineous marriages is high, thus, the chance of incidence of autosomal recessive disorders is likely to be high. The aim of this study is to investigate the clinical characteristics and genetics of spinal muscular atrophy (SMA) in children who presented to Aga Khan University, Karachi. Materials and Methods: This study was a retrospective review of the medical charts of children (neonate: 15 years) with discharge diagnosis of SMA during last 10 years. Demographic features, consanguinity, and diagnostic analysis (including genetic analysis) were noted. Results: During the study period 67 children had a discharge diagnosis of SMA. Werdnig Hoffman disease (SMA type I) was the commonest variant seen in 37 (56\%) children. Overall 68\% were infants. High parental consanguinity was observed in $68 \%$ of the study cohort. The history of delayed development and undiagnosed early death was observed in the families of 19 children. Genetic testing was performed in 22 (33\%) children. Survival motor neuron (SMN) I gene deletion was found in $19(86 \%)$ of the 22 patients in whom the gene analysis was done and $13(68 \%)$ were also positive for neuronal apoptosis inhibitory proteins (NAIP) deletion. Conclusion: SMA is not an uncommon neurodegenerative disorder in Pakistan and SMA type I was the most common type. SMNI gene deletion was the most common genetic deletion found in this study. In addition, family history of developmental delay and frequent early deaths highlights the need for implementation of prenatal diagnosis for early detection, effective control, and management of this disorder in Pakistan.
\end{abstract}

Key words: Consanguinity, NAIP, SMN 1, spinal muscular atrophy

\section{Introduction}

Spinal muscular atrophy (SMA) is a neurodegenerative disease characterized by progressive degeneration

\begin{tabular}{|l|l|}
\hline \multicolumn{2}{|c|}{ Access this article online } \\
\hline Quick Response Code: & Website: \\
& www.neurologyindia.com \\
\cline { 2 - 2 } & \\
\hline & \\
\cline { 2 - 2 } & \\
\hline
\end{tabular}

of alpha motor neurons, leading to muscle atrophy, paralysis, and even death. ${ }^{[1]}$ Mostly it has a recessive inheritance; however, autosomal dominant and X-linked inheritance has been documented. ${ }^{[2]}$ The reported incidence is about 1 in 10,000 live births with a carrier frequency of 1 in $50 .{ }^{[3]}$ The gene for SMA, survival motor neuron (SMN1) has been mapped on the 5q11.2-13.3 region and there are two copies of SMN gene: SMN1 and SMN2 ${ }^{[4]}$ Most common mutation found in SMA patients is homozygous deletion of SMN1 exon 7; however, many compound heterozygous subjects with different deletions and point mutation have been documented. ${ }^{[5]}$ All patients with SMA lack a functioning SMN1 gene 
and are thus dependent on their SMN2 gene for SMN protein, which is nonfunctional and rapidly degraded, leading to selective degeneration of spinal and cranial motor neurons. ${ }^{[6]}$

Phenotypically SMA has extreme variability and clinically classified: ${ }^{[7]}$ SMA type I (severe variant, Werdnig-Hoffman) with age of onset before 6 months, may not sit, and usually die before their second birthday; SMA type II (intermediate variant) with age of onset between 7-18 months, may sit but never stand and death usually after 2 years of age; SMA type III (mild variant, Kugelberg-Welander) with age of onset $\sim 18$ months of age and death is in adult life; and SMA type IV (adult varients) presents in the second or third decade, individuals walk during the adulthood and death occurs in adult life. ${ }^{[3]}$ There other form is SMA type 0 or embryonic form (lethal variant), characterized by reduced fetal movements between 30-36 weeks of pregnancy with a very short life expectancy. ${ }^{[8]}$ The clinical characteristics of the disorder are: hypotonia, symmetrical proximal weakness, atrophy, and reduced to absent deep tendon reflexes. ${ }^{[4]}$ Genetic diagnosis by using polymerase chain reaction (PCR)-based DNA methods have been developed to detect deletions in both SMN and Neuronal apoptosis inhibitory (NAIP) gene. ${ }^{[2,9]}$ SMA is an autosomal recessive and consanguineous marriage increases the risk of the disease in the family. High prevalence of SMA has been reported in Iran, Egypt, and Saudi Arabia where consanguineous marriage rates are high. ${ }^{[10-13]}$ Pakistan has one of the highest reported consanguineous marriage rate in the world, approximately $61 \%$ marriages. ${ }^{[14]}$ With this high-rate consanguineous marriage, we expect a high burden of SMA in Pakistan. This report describes the demographic features, clinical characteristics, and genetic diagnosis of children with SMA in the Pakistani population.

\section{Materials and Methods}

\section{Identification of study population}

This was a retrospective chart review of children (neonate, 15 years) seen in the last 10 years (January 2001 to December 2010) and children with a diagnosis of SMA were evaluated. The sources of subjects included in this study were (i) inpatients discharge records with a diagnosis of SMA, ICD code (International Classification of Disease, 2008 (ICD9) 335.1 and 335.1 and (ii) data from the electrodiagnostic laboratory and genetic laboratory (SMA gene analysis). This study was approved by the Institutional ethical review committee; Aga Khan University, Karachi.

\section{Case definition}

Diagnosis of SMA was considered in any child with generalized hypotonia, diffuse symmetrical proximal muscle weakness and atrophy, tremor of fingers and hands, tongue fasciculation along with absent or greatly decreased deep tendon reflexes ${ }^{[4]}$ and electromyographic (EMG) evidence of denervation, preganlionic anterior horn cells. ${ }^{[3]}$ Molecular genetic testing was aimed at detecting bi-allelic deletions or mutations in the survival motor neuron 1 (SMN1) gene on chromosome 5 q13 (exon 7 and exon 8) and/or neuronal apoptosis inhibitory protein (NAIP) gene. Muscle biopsy was not done in any of the patients.

\section{Gene analysis}

Genomic deoxyribonucleic acid (DNA) was isolated from blood samples using column based DNA extraction kit obtained from Promega (USA). Deletion of exon 7 and 8 of SMN 1 gene was examined by polymerase chain reaction (PCR) amplification and restriction endonuclease digestion according to the method of Steege et al. ${ }^{[15]}$ PCR amplification was carried out for 35 cycles in PCR mixture containing $100 \mathrm{ng}$ DNA, $75 \mathrm{ng}$ of each primer, $200 \mu \mathrm{M}$ of dNTPs, $1.5 \mathrm{MgCl} 2$, 2.5U Taq polymerase in a final volume of $50 \mu \mathrm{L}$. PCR products of exon 7 were digested with Dra I, and exon 8 with DdeI. The digestion pattern of the PCR product was evaluated according to the protocol described by Steege et al. ${ }^{[15]}$ The deletion of exon 5 of NAIP was identified by using the method described by Roy et al. ${ }^{[16]}$ Along with exon 5; exon 13 of NAIP was also amplified and used a control to monitor the performance of PCR assay.

\section{Statistical analysis}

The retrieved data were analyzed on SPSS version 19. Demographic features included age in days, weight, gender, presenting complaint at admission or health seeking, year of admission, consanguinity, perinatal depression, developmental delay or any other early death/s within the family were retrieved. Electromyography and nerve conduction study (EMG/ $\mathrm{NCV}$ ) and genetic analysis data were also retrieved and reported. SMN and NAIP gene mutations were reported among positive patients. Because of descriptive nature of the data only frequency and percentages were calculated.

\section{Results}

After chart review during the study period 67 children who fulfilled the inclusion criteria. Of the 67 patients $42(63 \%)$ were infants and 7 were neonates. There was male predominance, $38(57 \%)$ and male to female ratio was 1.2:1. Children were further divided according to the SMA types 1 to 3 [Table 1]. Developmental delay was the main presenting feature $(45 \%)$ followed by, generalized weakness, hypotonia and respiratory difficulty. SMA type I accounted for 56\% $(n=37)$ of the cohort. Mean age at presentation in SMA-type 1 was $3.3 \pm 1.7$ months (median; 3 months). Overall 
Table 1: Baseline features and genetic identification of children with spinal muscular atrophy

\begin{tabular}{|c|c|c|c|}
\hline Variables^ & $\begin{array}{c}\text { SMA type } 1 * \\
(n=37)\end{array}$ & $\begin{array}{c}\text { SMA type } 2^{*} \\
(n=15)\end{array}$ & $\begin{array}{l}\text { SMA type } \\
3^{*}(n=15)\end{array}$ \\
\hline $\begin{array}{l}\text { Mean age of } \\
\text { presentation }( \pm S D)\end{array}$ & $3.3 \pm 1.7 \mathrm{mo}$ & $15 \pm 4 \mathrm{mo}$ & $70 \pm 2 \mathrm{mo}$ \\
\hline $\begin{array}{l}\text { Male } \\
\text { Main presenting } \\
\text { complaint }\end{array}$ & $23(62 \%)$ & $6(40 \%)$ & $9(60 \%)$ \\
\hline Respiratory difficulty & 10 & 1 & -- \\
\hline Developmental delay & 14 & 7 & 9 \\
\hline Failure to thrive & -- & 1 & -- \\
\hline Weakness / Hypotonia & 7 & 4 & 5 \\
\hline Walking difficulty & -- & -- & 1 \\
\hline $\begin{array}{l}\text { Fever/ Lethargy/ } \\
\text { Sepsis/ Poor intake }\end{array}$ & 6 & 1 & -- \\
\hline Weight $<5^{\text {th }}$ centile & $10(33 \%)$ & $3(40 \%)$ & $5(36 \%)$ \\
\hline $\begin{array}{l}\text { Consanguinity in } \\
\text { parents }\end{array}$ & $21(66 \%)$ & $9(82 \%)$ & $6(60 \%)$ \\
\hline $\begin{array}{l}\text { Perinatal depression } \\
\text { Positive family history }\end{array}$ & $12(35 \%)$ & $6(54 \%)$ & $2(15 \%)$ \\
\hline Diagnosed SMA/ & $12(55 \%)$ & $4(50 \%)$ & $3(40 \%)$ \\
\hline $\begin{array}{l}\text { Developmental delay } \\
\text { Early deaths }\end{array}$ & $14(47 \%)$ & $3(27 \%)$ & $2(18 \%)$ \\
\hline $\begin{array}{l}\text { Genetic analysis of SMA } \\
\text { patients }\end{array}$ & & & \\
\hline $\begin{array}{l}\text { Exon } 7 \text { and } 8 \text { deleted in } \\
\text { SMN } 1 \text { gene }\end{array}$ & 2 & -- & 4 \\
\hline $\begin{array}{l}\text { Both NAIP and SMN } 1 \\
\text { gene deleted }\end{array}$ & 10 & 3 & -- \\
\hline Negative & 1 & 1 & 1 \\
\hline
\end{tabular}

*Adapted from reference(6) 'Because of missing values the data, the denominator was changed for each subcategory. Spinal muscular atrophy (SMA); survival motor neuron (SMN); neuronal apoptosis inhibitory (NAIP).

18 (31\%) children were severely malnourished (weight for age; $<5^{\text {th }}$ percentile). The history of parental consanguinity was present in $53(73 \%)$ children and them $36(68 \%)$ had consanguineous marriages [Figure 1]. Perinatal depression was positive among $20(34 \%)$ on the 58 children where such history was documented; while family history of developmental delay and/or spinal muscular atrophy was found in $19(45 \%)$ of 42 children where such history was documented. The history of early deaths in the family was present in $19(37 \%)$ of the 52 children with the data available. EMG/nerve conduction studies were performed in 62 patients, showing positive sharp waves, fibrillation, and/or fasciculation in all, and were consistent with the diagnosis of SMA.

Gene analysis was done in 22 children; among them 19 were positive (86\%), genetic testing results were negative in $3(13 \%)$ children. All positive patients showed a deletion of exon 7 and 8 in SMN1 gene. Exon 5 deletion of NAIP gene was also found positive in 13 (68\%) of the 19 patients [Table 1]. Out of 20 hospitalized patients $5(25 \%)$ children died. All died because of respiratory failure and were diagnosed as SMA type 1 . The mean age at death was $3.9 \pm 1.2$ months.

\section{Discussion}

Werdnig-Hoffman disease (SMA-1) is the most severe clinical type of SMA and prenatal onset of SMA has also been defined. ${ }^{[10,17]}$ It is associated with high morbidity and mortality. In our study majority of patients (61\%) were infants at the time of presentation similar to the observations in other studies. ${ }^{[10,17,18]}$ Males had a slightly higher preponderance than females in our study and this also has been reported in the literature. ${ }^{[10,17]}$ Consanguinity was very high in our study. The reported consanguinity in the earlier studies ranged between $38.9 \%$ and $49 \% \cdot{ }^{[10,17,19]}$ High consanguinity would reflect the autosomal recessive inheritance of this disease. Table 2 compares the consanguinity rates among SMA children from different countries. Early or previous deaths in family and history of developmental delay may be the additional features indicating a genetic background of this disease in our study cohort.

More than $98 \%$ of patients with spinal muscular atrophy have a homozygous disruption of SMN1 by deletion, rearrangement, or mutation. ${ }^{[3]}$ The clinical severity is influenced by the number of copies of SMN2 gene. It has been observed that $95 \%$ of SMA type I patients have only 1-2 copies of SMN2, whereas almost all patients belonging to type III had 3 or more copies. ${ }^{[20]}$ Because of this, the children belonging to these groups have less severe form of disease. ${ }^{[21]}$ The most common deletion found in our cohort was of SMN1. Exon 7 and 8 in SMN1gene was deleted in majority of positive children. Similar was the observation in the Egyptian cohort, in this study the frequency of homozygous deletion of exon 7 and 8 were present in $54.5-80 \%$ of patients irrespective of their clinical severity. ${ }^{[22]}$ In our cohort NAIP was the most common deletion (68\%) among children tested for genetic testing; $10(77 \%)$ of them were SMA type 1 . The frequency of NAIP deletion was also found to be more frequent in SMA type I ( $80 \%)$ as compared to type II $(22 \%)$ and type III (50\%) in the Egyptian cohort. ${ }^{[22]}$ However, the incidence was much higher $(100 \%)$ in the studies from Kuwait and Saudi Arabia. ${ }^{[10,13]}$ Interestingly all the three children with SMA II in our study had gene deletion for both NAIP and SMN1 gene. The reported frequency of NAIP deletion is relatively lower for both SMA II and III. ${ }^{[17,23]}$ Very few children with SMA II and SMA III had genetic testing and therefore we are unable to draw any significant conclusion from these results. Larger samples are needed to further explain the genetic basis of SMA type II and III patients in our population. Genetic testing was negative in three children. The 5q-SMA genetic testing is $95 \%$ sensitive and $100 \%$ specific. ${ }^{[23]}$ Fiver percent $(1 / 20)$ of affected individuals with 5q-SMA have rare point mutation that are not detected by the SMN genetic testing. Most of these children have one SMN1 gene with SMN1 exon 7 


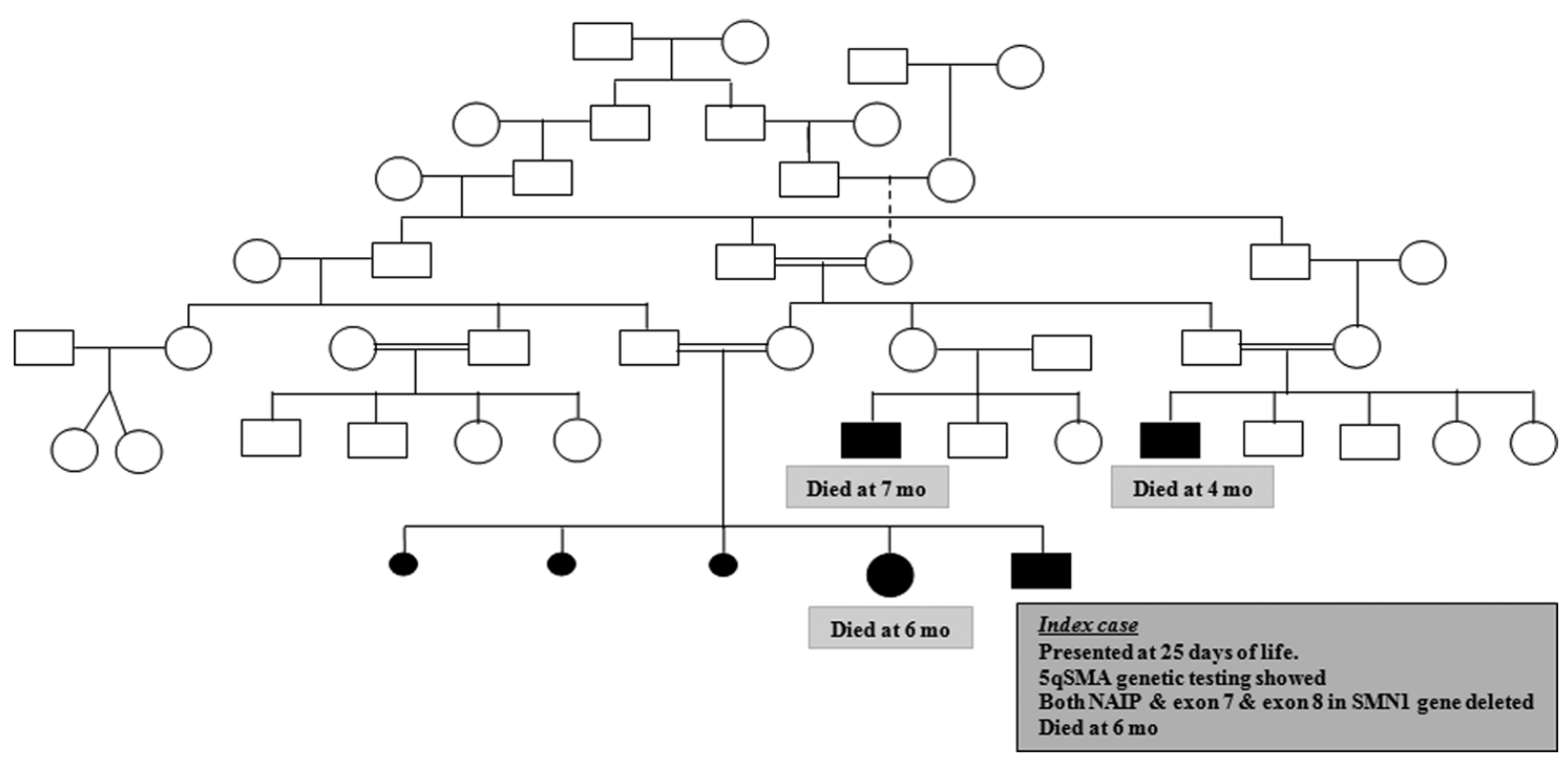

Figure 1: Family tree of a patient with SMA I

Table 2: Comparison of reported proportion of parental consanguinity in children with SMA

\begin{tabular}{lcl}
\hline $\begin{array}{l}\text { Author name and } \\
\text { study year }\end{array}$ & $\begin{array}{c}\text { Reported } \\
\text { proportion of } \\
\text { consanguinity }\end{array}$ & Country \\
\hline Shawky $(2011)^{[10]}$ & $46 \%$ & Egypt \\
Koul (2007) & $49 \%$ & Oman \\
Salahshourifar (2007) ${ }^{[12]}$ & $65 \%$ & Iran \\
Al Rajeh (1998) & $81 \%$ & Saudi Arabia \\
lbrahim et al. (our study) & $68 \%$ & Pakistan \\
\hline
\end{tabular}

missing and a second SMN1 gene with a rare point mutation. ${ }^{[23]}$

Currently there is no available cure for SMA; one possible intervention could be to reduce the consanguinity by educating the population. This will eventually interrupt the transmission by reducing carrier state. With the availability of genetic testing it is now possible to diagnose these children early so that appropriate counseling can be given to the family on the risk of future pregnancies. Early identification by genetic testing has also opened the way for early antenatal diagnosis.

\section{Limitations}

Genetic testing for SMA in our university was started from 2005; hence, data on genetic testing were only present for patients after this period. Some families denied genetic testing due to various reasons. With these limitations this is the first study from Pakistan that reports clinical spectrum and genetic testing of SMA patients.

\section{Conclusion}

SMA-1 is the commonest SMA type in our study population. Deletion of exon 7 and exon 8 in SMN1 gene is the commonest deletion in our SMA study cohort; however, an exon 5 deletion in NAIP gene is also very high. This study highlights the need for implementation of prenatal diagnosis in high risk consanguineous populations like Pakistan to reduce the burden of the disease.

\section{Acknowledgments}

Taher AT, Musallam KM, Cappellini MD. Thalassaemia Intermedia: an Update. Mediterr J Hematol Infect Dis 2009;1:e2009004. Available from: http://www.mjhid.org/ article/view/4709 [Last accessed on 2012 May 10].

\section{References}

1. Crawford TO, Pardo CA. The neurobiology of childhood spinal muscular atrophy. Neurobiol Dis 1996;3:97-110.

2. Shafeghati YT, Babamohammadi G, Afrouzan F, Almadani N, KarimiNejad R, Najmabadi H. Molecular diagnosis in Iranian patients with spinal Muscular atrophy. Arch Iranian Med 2004;7:47-52.

3. Lunn MR, Wang CH. Spinal muscular atrophy. Lancet 2008;371:2120-33.

4. Hausmanowa-Petrusewicz I, Vrbova G. Spinal muscular atrophy: A delayed development hypothesis. Neuroreport 2005;16:657-61.

5. Lorson CL, Hahnen E, Androphy EJ, Wirth B. A single nucleotide in the SMN gene regulates splicing and is responsible for spinal muscular atrophy. Proc Natl Acad Sei U S A 1999;96:6307-11.

6. Kolb SJ, Kissel JT. Spinal Muscular Atrophy: A Timely Review. Arch Neurol 2011;68:979-84.

7. Kaplan JC. Gene table of monogenic neuromuscular disorders (nuclear genome only) Neuromuscul Disord 2009;19:77-98.

8. Dubowitz V. Very severe spinal muscular atrophy (SMA type 0): An expanding clinical phenotype. Eur J Paediatr Neurol 1999;3:49-51. 
9. Omrani O, Bonyadi M, Barzgar M. Molecular analysis of the SMN and NAIP genes in Iranian spinal muscular atrophy patients. Pediatr Int 2009;51:193-6.

10. Shawky RM, El-Syed NS. Clinico-epidemiologic characteristics of spinal muscular atrophy among Egyptians. Egypt J Med Hum Genet 2011; [In press].

11. Kesari A, Rennert H, Leonard DG, Mittal B. SMN1 dosage analysis in spinal muscular atrophy from India. BMC Med Genet 2005;6:22.

12. Salahshourifar I, Shafeghati Y, Golkar Z, Najmabadi H. Molecular analysis of the neuronal apoptosis inhibitory protein gene in families with spinal muscular atrophy. Arch Iran Med 2007;10:509-13.

13. Al Rajeh S, Majumdar R, Awada A, Adeyokunnu A, Al Jumah M, Al Bunyan M, et al. Molecular analysis of the SMN and NAIP genes in Saudi spinal muscular atrophy patients. J Neurol Sci 1998;158:43-6.

14. National Institute of Population Studies (NIPS) [Pakistan] and Macro International Inc. 2008. Pakistan Demographic and Health Survey 2006-07. Islamabad, Pakistan: National Institute of Population Studies and Macro International Inc; 2008.

15. van der Steege G, Grootscholten PM, Cobben JM, Zappata S, Scheffer H, den Dunnen JT, et al. Apparent gene conversions involving the SMN gene in the region of the spinal muscular atrophy locus on chromosome 5. Am J Hum Genet 1996;59:834-8.

16. Roy N, McLean MD, Besner-Johnston A, Lefebvre C, Salih M, Carpten JD, et al. Refined physical map of the spinal muscular atrophy gene (SMA) region at $5 q 13$ based on YAC and cosmid contiguous arrays. Genomics 1995;26:451-60.

17. Koul R, Al Futaisi A, Chacko A, Rao V, Simsek M, Muralitharan S, et al. Clinical and genetic study of spinal muscular atrophies in Oman. J Child Neurol 2007;22:1227-30.

18. Shawky RM, Abd el-Aleem K, Rifaat MM, Moustafa A. Molecular diagnosis of spinal muscular atrophy in Egyptians. East Mediterr Health J 2001;7:229-37.

19. Al-Jumah M, Majumdar R, Al-Rajeh S, Awada A, Chaves-Carbello E, Salih M, et al. Molecular analysis of the spinal muscular atrophy and neuronal apoptosis inhibitory protein genes in Saudi patients with spinal muscular atrophy. Saudi Med J 2003;24:1052-4.

20. Mailman MD, Heinz JW, Papp AC, Snyder PJ, Sedra MS, Wirth B, et al. Molecular analysis of spinal muscular atrophy and modification of the phenotype by SMN2. Genet Med 2002;4:20-6.

21. Prior TW. Spinal muscular atrophy diagnostics. J Child Neurol 2007;22:952-6.

22. Essawi ML, Effat LK, Shanab GM, Al-Ettribi GM, El-Haronui AA, Karim AM. Molecular analysis of SMN1 and NAIP genes in Egyptian patients with spinal muscular atrophy. Bratisl Lek Listy 2007;108:133- 7 .

23. D'Amico A, Mercuri E, Tiziano FD, Bertini E. Spinal muscular atrophy. Orphanet J Rare Dis 2011;6:71.

How to cite this article: Ibrahim S, Moatter T, Saleem AF. Spinal muscular atrophy: Clinical spectrum and genetic mutations in Pakistani children. Neurol India 2012;60:294-8.

Source of Support: Nill, Conflict of Interest: None declared.

Staying in touch with the journal

1) Table of Contents (TOC) email alert

Receive an email alert containing the TOC when a new complete issue of the journal is made available online. To register for TOC alerts go to www.neurologyindia.com/signup.asp.

2) RSS feeds

Really Simple Syndication (RSS) helps you to get alerts on new publication right on your desktop without going to the journal's website. You need a software (e.g. RSSReader, Feed Demon, FeedReader, My Yahoo!, NewsGator and NewzCrawler) to get advantage of this tool. RSS feeds can also be read through FireFox or Microsoft Outlook 2007. Once any of these small (and mostly free) software is installed, add www.neurologyindia.com/rssfeed.asp as one of the feeds. 